\title{
The Effect of Halal Destination Image and Visitors Satisfaction on Tourist Loyalty (Object In Bukit Tinggi City Of West Sumatera)
}

\author{
Elfitra Desy Surya \\ Departement of Management \\ Universitas Sumatera Utara \\ Medan, Indonesia \\ Elfitradesysurya1972@yahoo.co.id
}

\author{
Endang Sulistia Rini \\ Departement of Management \\ Universitas Sumatera Utara \\ Medan, Indonesia \\ endangsulistyarini@yahoo.co.id
}

\author{
Nasrudin Setiawan \\ Departement of Management \\ University Of Pembangunan Panca Budi \\ Medan, Indonesia \\ snasruddin@gmail.com
}

\begin{abstract}
This research aims to clarify: the influence image of halal destinations variable and to tourist satisfaction variable Against tourist loyalty in Bukit Tinggi city. This research uses quantitative approach with explanatory research. This research uses three variables: tourist satisfaction, image of halal destinations, and tourist loyalty. The collection of data obtained through a questionnaire which distributed to 210 respondents. The sampling technique using purposive sampling with the population of the archipelago tourists came from outside the city of Bukit Tinggi, who visited at least twice to the tourist attraction in Bukit Tinggi City for a tour. Analysis of this research data using descriptive analysis and path analysis. The result of the research shows that the image variable of halal destinations and the satisfaction of tourists has a significant effect on the loyalty variable of tourists. Based on the results of the research, regional government and tourism businesses should maintain the image of Bukit Tinggi City to increase the intensity of tourist visits by promoting all kinds of tourist attraction, in Bukit Tinggi City and optimizing the tourist attraction in Bukit Tinggi City by making tourism packages.
\end{abstract}

Keywords: Halal Destination Image, Visitors Satisfaction, Tourist Loyalty, Bukit Tinggi city

\section{INTRODUCTION}

The tourist destination is one part of tourism development Indonesia. The range of components of a destination tourism among the objects and attractions, accessibility, amenities (tourism support facilities), supporting facilities, and institutions (Sunaryo, 2013). One of the cities that surrounds five component of halal tourism destinations in West Sumatera namely Bukit Tinggi City.
Table 1 The Top Ten Destination Countries Organization of Islamic Cooperation (OIC) and Non-OIC in Global Muslim Travel Index (GMTI

\begin{tabular}{|c|c|c|c|c|}
\hline Peringkat & Destinasi 0IC & Skor & Destinasi Non-0IC & Skor \\
\hline 1 & Malaysia (1) & 83,8 & Singapura (9) & 65,1 \\
\hline 2 & Turki (2) & 73,8 & Thailand (20) & 59,2 \\
\hline 3 & UEA (3) & 72,1 & Inggris (25) & 55,0 \\
\hline 4 & Saudi Arabia (4) & 71,3 & Afrika Selatan (30) & 51,1 \\
\hline 5 & Qatar (5) & 68,2 & Perancis (31) & 48,2 \\
\hline 6 & Indonesia (6) & 67,5 & Belgia (32) & 47,5 \\
\hline 7 & Oman (7) & 66,7 & Hongkong (33) & 47,5 \\
\hline 8 & Jordania (8) & 66,4 & Amerika Serikat (34) & 47,3 \\
\hline 9 & Moroko (9) & 64,4 & Spanyol (35) & 46,5 \\
\hline 10 & Brunei (10) & 64,3 & Taiwan (36) & 46,2 \\
\hline \multicolumn{5}{|c|}{ Source: Crescen Rating, GMTI Report 2017 }
\end{tabular}

Based on Table 1 The Global Muslim Travel Index (GMTI) 2015 in the Destination of Islamic Cooperation (OIC) destinations group, Indonesia (index score 67.5) is ranked sixth after Qatar (index score 68.2), Saudi Arabia (index score 71.3), United Arab Emirates / UAE (index score 72.1), Turkey (index score 73.8), and Malaysia (index score 83.8). While Singapore became the main destination for non-OIC destinations, where Thailand, England, South Africa, and France are also included

Potential tourist attraction owned by West Sumatra, especially Kota Bukit Tinggi is a natural attraction beaches, cultures, creative economy (embroidery and songket) as well as a very diverse culinary and historical relics. West Sumatra is one of the main destinations of halal tourism in Indonesia. This should be a factor driving tourists to come to this province.

Some international events organized to support 
West Sumatra tourism are the Tour de Singkarak cycling race, Event Fly for Fun event in Lake Maninjau, and the Mentawai International Pro Surf Competitive cheese championship. In addition, West Sumatra also has a distinctive cultural festival such as Tabuik Festival, Rendang Festival, game kim. Besides, Sumatra has a very famous craft to the Abroad that is embroidered that has a distinctive characteristic and songket cunning very interesting motifs and patterns.

West Sumatra is also renowned for its strong customs known for the term "adat Basandi Sarak, Sarak Basandi Kitabulah

.Bukit Tinggi City as a destination of halal tourism is shown through data related to tourist attraction and accessibility listed in Central Bureau of Statistics (BPS) of West Sumatera Province (2016). Bukit Tinggi city has a variety of tourist attractions, both artificial tourist attraction, culture, culinary, historic relics, crafts such as embroideries and embroidery and natural attractions Accessibility in the City of Bukit Tinggi, for the road $70 \%$ in good condition. Bukit Tinggi city already has public transportation modes that can be utilized by tourists, there is also provided by some tourist attraction to support tourism activities.

The city of Bukit Tinggi in terms of amenities, in 2016, has a number ten of star hotels and twenty two nonstar hotels a number of fruits (Central Bureau of Statistics Bukit Tinggi, 2016). In addition, there are also restaurants or restaurants spread across the city of Bukit Tinggi, especially around the tourist attraction.

Supporting facilities available include Banks, Hospitals, and telecommunications, souvenir shopping places and others. As a historical and cultural city of Bukit Tinggi, it has a very interesting historic place that is the Japanese pit and canyon gorge. In addition Bukit Tinggi city is famous for its souvenir and craft city.

The city of Bukit Tinggi as a tourism destination, halal in its development would require some benchmarks, one of them from the tourists. Tourists are considered important to assess a halal destination because tourists are buyers or connoisseurs of services (services) offered by halal tourism destinations. Tourists judge a halal destination through their beliefs and perceptions of halal products including halal culinary with halal label from MUI and other facilities that already fulfill one of the halal standards of cleanliness, which can then be referred to as the destination image

The image of destination (destination image) halal tourism is a belief knowledge about destinations and what is felt by tourists during the tour. Another factor for development. Halal tourism destinations in accordance with what is needed by tourists is to pay attention to things that affect tourist satisfaction. The satisfaction of tourists as buyer or service connoisseur may be considered through the overall assessment of tourists. Assessment is related to the quality of the results. Halal tourism destinations obtained by tourists. The development of a good halal tourism destination, of course, can make tourists feel satisfied and then can make tourists plan to visit again or recommend halal tourism destinations related to others. The behavior of tourists after the visit can be called the loyalty of tourists.

Destination image (destination image) halal can affect the satisfaction of tourists (tourist satisfaction) and the loyalty of tourists (tourist loyalty). Coban (2012) proved in his research that the image of a positive destination will make the tourists feel satisfaction better. Coban (2012) also explained that travelers are positive rate against the image of a destination may be willing visit again and recommend related destinations to others. Research that done by Coban (2012) also shows that satisfaction has a positive effect against behavior after purchase (visiting).

The urgency of this study, with knowing the opinions of travelers about the image halal destinations Kota Bukit Tinggi, it is expected that the development of tourism in Kota Bukit Tinggi can be aligned with what the tourists need. Moreover, West Sumatra has been awarded the award of World Halal Tourism Award 2016 (WHTA 2016) for the category of halal tourism destinations. So with the awards that have been received by the Province of West Sumatra expected tourists could get satisfaction and future plans to repeat his visit or at least recommend to other parties (brother friends and others) so that the city of Bukit Tinggi as one tourist destination halal in West Sumatra Province worth visiting.

Table 2 Data of foreign and domestic tourists visiting West Sumatra

\begin{tabular}{|c|c|c|}
\hline Year & $\begin{array}{c}\text { Foreign Tourist } \\
\text { (people) }\end{array}$ & $\begin{array}{c}\text { NusantaraTourist } \\
\text { (People) }\end{array}$ \\
\hline 2012 & 36,623 & $5,948.295$ \\
\hline 2013 & 48,710 & $6,261.363$ \\
\hline 2014 & 56,111 & $6,605.738$ \\
\hline 2015 & 48,755 & $6,973.678$ \\
\hline 2016 & 49,686 & $7,343.282$ \\
\hline
\end{tabular}

Source: Tourism and Creative Economy Department of West Sumatera Province in 2017

Table 2 shows that the number of foreign tourist arrivals in 2012 to the year 2014 has increased, but in 2015 and 2016 visits foreign tourists decreased this is allegedly because the marketing mix has not been able to provide satisfaction both in terms of tourism products, tourist attractions complete with facilities and infrastructure owned, and the promotion of tourist destinations that have not maximized, physical of evidence, people (HR) working in the tourism industry, and the processes that exist in the tourism, in addition to the security and comfort of tourists in the tourist attraction to support to achieve the satisfaction of tourists. 
Table 3 The data of Foreign Tourist and local travelers visiting the Bukit Tinggi City (2012-2016)

\begin{tabular}{|c|c|c|}
\hline Year & $\begin{array}{c}\text { Foreign Tourist } \\
\text { (People) }\end{array}$ & $\begin{array}{c}\text { local travelers } \\
\text { (people) }\end{array}$ \\
\hline 2012 & 26,802 & 360,192 \\
\hline 2013 & 32,068 & 404,145 \\
\hline 2014 & 32,501 & 400,537 \\
\hline 2015 & 32,600 & 400,798 \\
\hline 2016 & 35,780 & 564,220 \\
\hline
\end{tabular}

Source: Office of Culture and Tourism Bukit Tinggi City, 2015

Table 3 we can see that a number of visits tourists both overseas and the archipelago who visit and stay at Bukit Tinggi is increasing every year. We can see in 2012 he number of visits is only 26.802 foreign tourist arrivals and 360.192 visit local travelers while in 2014 to 32,501 visits of foreign tourists and 400,537 tourists visit local travelers. The number of visits should be an opportunity for the object manager tours to improve facilities and infrastructure order for the number of visits to

respectively each tourist attraction is also increase

Also, it can be known what factors should be maintained and enhanced from the attributes of halal tourism in the city of Bukit Tinggi and analyze whether the idea of a negative tourist from the image of Bukit Tinggi as a halal tourism so that the required improvement support the quality of more halal tourism destinations good. Based on the exposure, the formula the problem of this research there are three, namely:

\section{LITERATURE REVIEW}

\section{A. Halal Tourism (Halal Tourism)}

Halal tourism is: Shariah Tour or Halal Tourism is one of the tourism systems that is in the allotment for Muslim tourists whose implementation obeys the rules of Sharia (Munirah, 2012). In this case the hotel that carries sharia perhaps does not serve alcoholic beverages and has a pool and separate spa facilities for men and women. The launch of sharia tourism coincides with the activities of Indonesia Halal Expo (Index) 2013 \& Global Halal Forum held on 30 October to 2 November 2013. Halal tourism promotes halal and safe products consumed by Muslim tourists. However, it does not mean non-Muslim tourists can not enjoy halal tours. For Muslim tourists, halal tourism is part of da'wah. For non-Muslims, sharia tours with halal products is a healthy guarantee. Because in principle, the implementation of halal rules that means removing the things that harm to humanity and the environment in products and services provided, and certainly provide the good or the benefit in general

\section{B. Destinations (Destination)}

Destinations by Seaton and Bennet (1996) is a unified tourism destination product but consists of various types of organizations and operations tourism in its geographical area, including hotels, transportation, attractions, and others. Destinations tourism includes everything that is on regions, both communities, landscapes, other industries, and anything else that can be part of destination experience, local uniqueness that can be enjoyed by tourists though not part of tourism economy in particular. Destinations within development framework include several main components. The main components according to Sunaryo (2013) is divided into five, includes objects and attractions, accessibility, amenities, ancillary services, and institutions.

Destination Image (Destination Image) The image (image) of tourism according to Pitana and Diarta (2009) is the belief possessed by tourists about the products or services that tourists buy or will buy in accordance with halal standards. Destination imagery is not always formed by experience or facts but can be formed to be a strong motivating factor or driving force to travel travelers to a tourism destination. The image of a destination based on a tourist judgment may vary from person to person. Coban (2012) in his research explains that the image of the destination consists of the results of rational assessment or cognitive image (cognitive image) and emotional assessment or affective image (affective image) of the destination itself. Imagery of Halal Tourism Destination (Halal Tourism Destination)

Imagery of Halal Tourism Destination (Halal Tourism Destination) One way we can do in building the image of halal tourism in West Sumatra is by Place Branding. According to Robert Govert and Frank Go the definition of place branding is Place branding as a marketing activity (1) that supports the creation of a name, logo, symbol, word mark or other graphics. Good for identifying and differentiating goals, (2) delivering promises from a unique travel experience memorably related to the destination (3) and serves to consolidate and strengthen memories fun from experience to influence consumer decisions visiting tourist destinations (Blain Levy \& Ritchie, 2005; and Govers \& Go, 2009). 3 assessment themes GMTI 2016 Safe and friendly destination for holiday activities family. The facilities and service are friendly Muslim. Marketing and awareness of destinations about halal tours is

a. Safe and friendly destinations for family holiday activities

1. Family friendly tourist destination

2. Security in general and specifically for Muslim tourists

3. The number of Muslim visits

b. Muslim friendly facilities and services

1. Choice and guarantee of halal food

2. Praying Facilities

3. Airport facilities

4. Choice of accommodation 
c. Marketing and awareness of destinations about Halal tours

1. Ease of communication

2. Awareness of the needs of Muslim

tourists and efforts to fulfill it

3. Air Transportation

4. Visa Requirements

Cognitive image according to Coban (2012) explains the beliefs and information possessed someone about a destination. Dimensions of six cognitive imagery, is tourist attraction (touristy traditions), basic facilities (basic facilities), attractions culture (cultural attractions), accessibility and tourism substructure (touristy substructures and access), natural environment, and economic factors (variety and economical factors). While the affective image according to Artuger et al. (2013) is a picture of emotions or feelings someone is a traveler about a destination. Artuger et al. (2013) divide the dimension affective image into three, the living city (lively city), a vibrant city (exciting city), and a nice city (pleasant city).

Tourist Satisfaction Satisfaction by Kotler and Keller (2008) is a feeling of disappointment or the pleasure that a person feels arises as a result of comparing perceived performance products (or outcomes) to buyer expectations. Tourist satisfaction is a measure overall from the opinions of travelers on every quality of destinations (Prayag, 2008 in Coban, 2012). The size can be considered as a value about the quality of the results of the destination tourism, such as treatment and services felt by tourists towards tourism destinations, but not just the result at the end of his experience (Coban, 2012). Yuksel et al. (2010) measure satisfaction with three items, first relating with the pleasure or not of the tourists against his decision to visit the destination tourism, the second is the belief that chooses related destinations are the right thing, and third overall satisfaction level over travel to tourism destinations.

\section{Tourist Loyalty}

Loyalty is a customer's willingness to constantly use the product of a company in the long run, even use it exclusively, recommends such products on others (Lovelock et al., 2010). Sramek et al. (2008) within in Artuğer et al. (2013) defining loyalty is repeating purchase, positive attitude, long commitment long, intend to continue the affiliation and spreading positive information to others. Willingness to use the company's products in the long run, in related tourism with the willingness of tourists to visit return to a destination in the future.

Artuger et al. (2013) explain the deciding factor loyalty to tourism destinations there are two. First, Intention to revisit the destination, that is that tourists show their loyalty by revisiting tourism destinations related in the future. Second, Say positive things about the destination and recommendations to others, meaning that tourists show his loyalty by saying things-a positive thing about tourism destinations then recommend the tourist destinations to others

Imagery Image Relationship with Travelers Travelers and Travelers Loyalty. Coban (2012) to prove the influence of a significant image of the destination to the satisfaction of tourists. The positivity of a destination image leads to high satisfaction and a negative image causing dissatisfaction or displeasure. Sun et al. (2013) through his research at Hainan tourism destinations, China as well prove that travelers develop a positive perception (image) of Hainan get better satisfaction on experience. It proves that the image of the destination has a positive effect on satisfaction of tourists while visiting destinations tourism.

Tasci and Gartner (2007) in Artuğer et al. (2013) explains that the image of the destination affect the behavior of tourists like intends to revisit, recommend it to someone else, or visit back to tourist destinations. Artuğer et al. (2013) through his research as well proves that there is a strong relationship and positive between the destination image with loyalty to the destination, and show that cognitive image has more influence to loyalty than affective image. Based on this it can be concluded that the behavior of tourists in the future that rate positive towards the image of a tourism destination the possibility is to revisit and to recommend related tourism destinations to others. Lovelock et al. (2010) explain that true loyalty lies in customer satisfaction (tourists) where tourists who are very satisfied or enjoy the service tend to be loyal supporters company (tourism destinations). Form of loyalty it can be a combination of all purchase with one service provider, in terms of tourism is by returning to visit a common destination, and spreading positive news related to the destination.

\section{Conceptual Framework}

The hypothesis that describes the influence of the image of the destination to the satisfaction of tourists and its impact on tourist loyalty can be seen in Figure 1

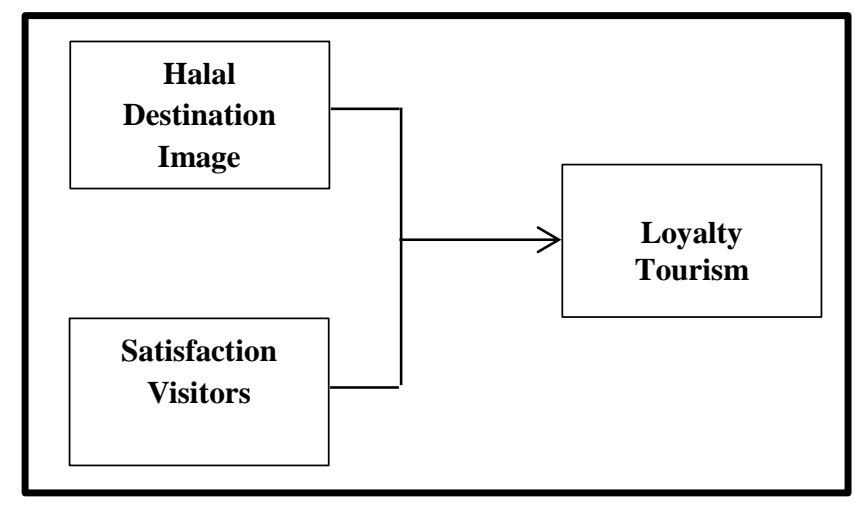

Figure I. Latent variable relations frame Work 
Hypothesis

1. Whether the image of halal tourism destinations have a positive and significant impact on the loyalty of tourists in the city of Bukittinggi?

2. Whether visitors Satisfaction a positive and significant impact on the loyalty of tourists in the city of Bukittinggi?

3. Whether the image of halal tourism destinations and visitors Satisfaction have a positive and significant impact on the loyalty of tourists in the city of Bukittinggi?

\section{RESEARCH METHODS}

\section{A. Population and Sample}

Population in this study are all visitors Bukittinggi city, west Sumatera who ever made a purchase weaving Bukittinggi city at the object Bukittinggi city. Sample selection is done by purposive sampling, where technique of determination of sample done with certain consideration. The sample of the respondents in this study is the visitors Bukittinngi city and not the local person's population of 210 persons.

\section{B. Operational Definition}

In this research, divided 3 of independent variables, include image of halal tourism destinations (X1), Satisfaction (X2), (X3) then dependent variables are Loyalty(Y).

\section{Method Data Analyze}

Data analysis method which used in this research by using multiple regression with model to know how big influence the image of halal destination, satisfaction and loyalty of visitors at Bukittinggi city West Sumatera. Researches used to helped of SPSS (Statistic Product and Service Solution) using multiple linear regression formulated as follow :

$\mathrm{Y}=\mathrm{a}+\mathrm{b} 1 \mathrm{X} 1+\mathrm{b} 2 \mathrm{X} 2$

Hypo test :
a. Simultan test ( $\mathrm{F}$ test )
b. Partial test ( $\mathrm{T}$ test )
c. Coefficient of determination $\left(\mathrm{R}^{2}\right)$

\section{ANALYZE AND DISCUSSION}

The influence of product innovation, product quality and city image towards the decision of the purchase of visitors on the tourist object Berastagi North Sumatera.

Based on multiple regression equation in this research was : $\mathrm{Y}=0.271 \mathrm{X} 1+0.245 \mathrm{X} 2$ Coefficient of determination

The magnitude of the effect of independent variables on the dependent variables is to use the following test coefficient of determination $\left(\mathrm{R}^{2}\right)$ as bellow :
Table.4. Coefficient of Determination Test.

\begin{tabular}{ccccc}
\hline Model & $\mathrm{R}$ & R Square & $\begin{array}{c}\text { Adjusted R } \\
\text { Square }\end{array}$ & $\begin{array}{c}\text { Std. Error of the } \\
\text { Estimate }\end{array}$ \\
\hline 1 & $.854^{\mathrm{a}}$ & .729 & .721 & 1.524 \\
\hline \multicolumn{5}{c}{ Resources: results of data processing, 2017 }
\end{tabular}

In table 4 obtained the score Adjusted R Square of 0,854 which means that the image of halal tourism destinations (X1), Satisfaction (X2) can explain the variation of the royalty tourism amount to $85,4 \%$ and the rest $14,6 \%$ influenced by other variables outside of the variables studies such as service quality

\section{A. F Test (Simultaneous)}

Table.5

F test (Simultaneous)

\begin{tabular}{ccccccc}
\hline \multicolumn{7}{c|}{$\mathbf{A N O V A}^{\mathbf{b}}$} \\
\hline Model & $\begin{array}{c}\text { Sum of } \\
\text { Squares }\end{array}$ & df & $\begin{array}{c}\text { Mean } \\
\text { Square }\end{array}$ & F & Sig. \\
\hline 1.Regression & 662.998 & 3 & 220.999 & 95.121 & $.000^{\mathrm{a}}$ \\
\hline Residual & 246.275 & 106 & 2.323 & & \\
\hline Total & 909.273 & 109 & & & \\
\hline
\end{tabular}

Resources: results of data processing, 2017

In table 5 reach the result of test $F$ count 95,121 with $F$ table in $\alpha=0.05$ and degree numerator 3 and degree denominator 106 reach $\mathrm{F}$ table around 3.23. So this result is known $\mathrm{F}$ count $>\mathrm{F}$ table and significant 0.000 or smaller than $\alpha=0.05$. It can be concluded that $\mathrm{H}_{1}$ accepted which means the image of halal tourism destinations, Satisfaction together have a significant effect on the loyalty of visitors.

B. T test ( Partial)

Table 6

Results of T Test (Partial)

\begin{tabular}{lcc}
\hline \multicolumn{3}{c}{ Coefficients $^{\mathbf{a}}$} \\
\hline \multicolumn{1}{c}{ Model } & $\mathrm{t}$ & Sig. \\
\hline 1 (Constant) & 3.306 & .002 \\
\hline Halal Destination Image & 12.815 & .000 \\
\hline Visitors Satisfaction & 3.131 & .000 \\
\hline Resources : results of data processing, & 2017
\end{tabular}

1.In table 6 , score $\mathrm{t}$ count for the image destination halal (12.815) larger than score of t table $(1,65)$ or score sig $t$ for the image destination halal $(0,000)$ more smaller than alpha $(0,05)$. Based on this result it reject $\mathrm{H}_{0}$ and accept $\mathrm{H}_{1}$ for This means that the image destination will give influence to the loyalty of tourists visiting the high hill town because the better the destination then the tourists will be satisfied. Once satisfied then tourists will make repeat visits (loyalty of tourists)

2. Score t count for visitor satisfaction (3.131) more large compare to score $\mathrm{t}$ table (1.65) or score sig t for satisfaction $(0,000)$ smaller than alpha $(0,05)$. Based on the result to reject Ho and accept $\mathrm{H}_{1}$ for satisfaction. This portially the satisfaction significantly influence the loyalty of visitors means that the satisfaction visitor formed with good will have a real impact on improving loyalty. 


\section{DISCUSSION}

\section{A. The Halal Destination Image Effect (XI) to Royalty} Tourism (YI)

The result of path analysis which explains that directly the destination image variable has an effect significantly to the satisfaction variable.Based on these results can be concluded that the satisfaction of tourists can be created with a positive destination image. Travelers who have a positive assessment of the destination related tourism, in Bukittinggi city then get high satisfaction. Instead, if the traveler has a negative rating, then tend to cause a sense of dissatisfaction or unhappy with tourism destinations.

The results of this study are in line with the research of Sun, et al. (2013) which concluded that tourists who develop that perception positive gain better satisfaction on experience. The results of this study also reinforce the results of. Coban research (2012) which proves the positive influence of image variable destination to variable satisfaction of tourists.

This study strengthens Coban (2012) research, especially general cognitive image indicators there are six items related to knowledge belief about a tourist tourism destinations, consisting of tourist attractions, basic facilities, cultural attractions, and accessibility tourism substructure, natural environment, and factors economy. Then also at the same time strengthen research results Artuğer et al. (2013) on the indicator affective imagery consisting of living city items, a vibrant city, and a city fun. The results are also aligned with research Mohamad et al. (2011) ones proves that the image has a positive effect on the satisfaction of tourists.

The Assessment great influence on the satisfaction that is natural beauty and also good facilities. The influence of halal destination image (X1) on satisfaction tourists (Y1) also supported from the suitability between the knowledge of tourists about Bukittinggi city with the reason for his visit. Based on description of respondent characteristics, in large part respondents know or know Bukittinggi city as a Tourist City. That knowledge encourages tourists to visit the Bukittinggi city with specific reasons motivations related to tourism activities. The reason that most respondents choose is to refresh the mind and body, and for fun.

\section{B. The Effect of Visitor Satisfaction (X2) to t Loyalty Tourism (Y1)}

Halal destination image variable on the test result of the analysis pathway, directly have a significant effect against the loyalty variable of tourists with contribution. The results show that travelers who have a positive rating about Bukittinggi city as a tourism destination can be loyal to Bukittinggi city. Traveler who already has knowledge or beliefs about cognitive imagery (tourist attractions, basic facilities, cultural attractions, and accessibility tourism substructure, natural environment, and factors economic) and effective image (living city, excited, and fun) from Bukittinggi City can be loyal by doing behavior certain.
The behavior of tourists such as intends to revisit in time coming up, saying positive things, and recommend Bukittinggi city to others. The influence of the destination image variable against the loyalty of tourists in line with research Artuger et al. (2013) which concluded that there is a positive influence. This research also strengthened the results of Tasci and Gartner's research (2007) in Artuger et al. (2013) explains that the image of the destination affects tourist behavior which among others intends (interest) revisit, recommend to another person, or a return visit to the destination related tourism. In addition, it also strengthens research Lobato et al. (2006); Chen and Tsai (2007); and Prayag (2008) in Coban (2012) which confirms that behavior is in the past front which positively assesses the image of a tourism destinations include visiting and recommending related destinations to others. Form of behavior loyalty of tourists against Bukit Tinggi city can be seen in the picture characteristics of respondents so that the city can be recommended to others

Travelers who recommending a tourist destination to others usually also say thing which is positive about the tourism destinations. This shows that respondents rate Bukit Tinggi city is a worthy tourism destination visited mainly for tourism activities

C. The Influence of Halal Destination Image (XI) and Visitors Satisfaction (X2) to Loyalty Tourism (Y1)

This study shows there is influence significantly variable satisfaction of tourists against the loyalty variable of tourists. This explains that satisfied tourists will tend to loyal to tourism destinations halal visited, in this research that is Bukittinggi city Travelers who get positive experiences and tend to be fun, more likely to be loyal tourists to Bukittinggi city compared with tourists who feel disappointed or dissatisfied.

This indicates that the higher the satisfaction of tourists towards tourism destinations, it will affect a higher degree of loyalty to related tourism destinations. Tourist behavior who feel satisfied after gaining experience travel in a tourist destination of the Bukittinggi City, in the future that behavior action is done as intended to revisit, say positive things, and recommend.

The form of real behavior of loyal tourists against the City Bukittingi one of them visible from the quantity of experience of his visit. It shows that tourists feel satisfied when visiting the Bukit Tinggi City and tend to make a return visit to gain a tourist experience, especially supported by a lot of tourist attraction in the City of Bukittinggi. Thus, tourists can visit to different tourist attractions every time to Bukittinggi City. This research supports Coban's research (2012), which results that the satisfaction of having positive influence on after behavior visiting, either by visiting back to the tourist destinations that have been visited and or recommend it to other people.

The results of this study are also in line with the theory put forward by Lovelock et al. (2010), that true loyalty to the company (tourism destinations) are found in satisfaction 
customers (tourists), where very satisfied or like the services provided. Form Such loyalty can be a visit returning the same tourism destinations and or with the opinions of Jones and Sasser (1995) in Lovelock et al. (2010) which is divided into three zones, namely diversion zone, ignorance, and affection. The diversion zone leads to tourists who tend to low satisfaction did not visit again, negative things related to tourism destinations visited.

Zone of indifference occurs on travelers who feel the satisfaction of being or gain experience equivalent in accordance with expectations, these tourists tend not to care and have the opportunity to move to the destination other tourism if have alternatives

\section{CONCLUSIONS AND RECOMMENDATIONS}

\section{A. Conclusion}

1. Halal destination image variable significantly proved to influence the loyalty of tourism.

2. Satisfaction visitor variable significantly proved to affect the loyalty of tourists.

3. The variable Halal destination image and satisfaction of tourists simultaneously significant affecting the loyalty of tourists.

\section{B. Suggestion}

1. It is expected that the Local Government of Bukittinggi City can maintain its image as a tourist city, with increasingly intense introducing and promote the brand (brand) owned, especially concerning its tourist attractions diverse. Strategies that can be done with provide innovation and its activities different and unique on a regular and periodic basis tourists interested to visit and enjoy the tourist attractions, as well as feel the different experiences each visiting Bukittinggi City, So, that has been in the city of Bukittinggi can be maintained and optimized in addition to the addition of tourist attraction.

2. Local Government of Bukittinggi City and business actor tourism should provide information and promotion of all kinds of tourist attraction because historical tourist attraction items are still awake, most respondents answered hesitantly. Such a comprehensive promotion effort can increase the number of visits tourists who are not just concentrated on power a certain tourist attraction but thorough on all types of tourist attraction owned by the City Stone. Other ways to include the various attractions are in the package tourism, so it can also be known by traveler. Another solution is to create activities (events) located at the attraction historical tour to attract visiting interest traveler.

3. The results of this study are still limited to variables image of halal tourism destinations, tourist satisfaction, and tourist loyalty. The authors hope that further research can use other variables beyond this study or add variables others are still related to that variable already in this research, so it can be on more in-depth analysis of how the model the structural image of the destination has an effect on loyalty of tourists, one of them related with service.

\section{REFERENCES}

Artuger, S., et al. 2013. The effect of destination image on destination loyalty: application in

Alanya. European Journal of Business and Management, 5 (13): 124-136.

Central Bureau of Statistics Bukittinggi city 2015. Bukittinggi city in Figures 2015, (Online), (accessed through http://batukota.bps.go.id on February $27^{\text {th }}$ 2016). 2015. Statistics of Bukittinggi City City 2015, (Online), (accessed via http://batukota.bps.go.id on February $\left.27^{\text {th }} 2016\right)$.

Coban, S. 2012. The effects of the image of destination on tourist satisfaction and loyalty: the case of Cappadocia. European Journal of Social Sciences, 29 (2): 222-232.

Kotler, P., and K. L. Keller. 2008. Management Marketing. Thirteenth Edition. Translated by Bob Sabran. Jakarta: Erland. Lovelock, et al. 2010. Marketing Services: Human, Technology, Strategy. Seventh Edition.

Translated by Dian Wulandari and Devri Barnadi Putera. Jakarta: Erland.

Pitana, I G., and I K. S. Diarta. 2009. Introduction to Science Tourism. Yogyakarta: Andi.

Seaton, A.V., and M.M. Bennett. Marketing Tourism Products: Concepts, Issues, Cases. UK: Thomson.

Sun, X., et al. 2013. Developing destination loyalty: The case of Hainan Island. Annals of Tourism Research, 43: 547-577.

Sunaryo, Bambang. 2013. Development Policy Tourism Destination: Concepts and Their Applications in Indonesia. Yogyakarta: Java Media. Law of the Republic of Indonesia Number 1 Year 2009 on Tourism.

Yuksel, A., et al. 2010. Destination attachment: Effects on customer satisfaction and cognitive, affective and conative loyalty. Tourism Management, 31: 274-284. 